\title{
A Compilation of the Geo-Mechanical Properties of Rocks in Southern Ontario and the Neighbouring Regions
}

\author{
Hayder Mohammed Salim Al-Maamori, Mohamed Hesham El Naggar*, Silvana Micic \\ Department of Civil and Environmental Engineering, Western University, London, Canada \\ Email: halmaamo@uwo.ca, ${ }^{*}$ helnaggar@eng.uwo.ca, ${ }^{*}$ naggar@uwo.ca, smicic2@uwo.ca
}

Received 10 April 2014; revised 8 May 2014; accepted 14 May 2014

Copyright (C) 2014 by authors and Scientific Research Publishing Inc.

This work is licensed under the Creative Commons Attribution International License (CC BY). http://creativecommons.org/licenses/by/4.0/

(c) (i) Open Access

\section{Abstract}

The available measurements of the geo-mechanical properties of rocks in Southern Ontario and the neighbouring regions (New York, Ohio, Michigan, Indiana, Illinois, Wisconsin, and Minnesota) are summarized and presented. These measurements were compiled from available published data in the relevant literature and also from data that were collected from major underground projects in these regions. The compiled data are presented in three categories: measured in-situ stresses in different rock formations; calculated strength, stiffness and deformation including time-dependent deformation properties; and the measured dynamic properties of intact rock specimens from different rock formations in Southern Ontario and the neighbouring regions. The data presented in this paper can be used as a resource for preliminary evaluation of the geomechanical properties of the rocks in these regions. The presented geo-mechanical properties were generally obtained from in-situ measurements and from laboratory tests that were conducted on intact rock specimens from freshly excavated rock samples. Moreover, the time-dependent deformation properties of rocks in these regions were obtained from laboratory tests that were performed on intact rock specimens submerged in water. However, the influence of drilling fluids such as bentonite slurry and synthetic polymers solution, on the geo-mechanical properties of rocks is not evident and needs to be investigated.

\section{Keywords}

Geo-Mechanical Properties, Rocks, Southern Ontario, Compilation

\footnotetext{
${ }^{*}$ Corresponding author.
} 


\section{Introduction}

The first step in the design process of underground structures in rocks is to define the strength and deformation parameters of the rock unit in addition to the initial in-situ stresses that exist at a specific depth in the hosting rock unit. During the past few decades, extensive investigations of the initial in-situ stresses in rocks of Southern Ontario and the neighbouring regions (New York, Ohio, Michigan, Indiana, Illinois, Wisconsin, and Minnesota) and their strength and deformation properties including time-dependent deformation properties were carried out. The investigations revealed that the rocks of these regions are subjected to high initial horizontal in-situ stresses that are of great influence on the deformation behaviour of these rocks with time.

The deformation of the rocks with time is known as time-dependent deformation behaviour, which was manifested as different types of distress on the existing underground structures in Southern Ontario [1]. These distresses were observed in the form of cracks in the tunnels lining at the springline, invert heave, buckling of lining concrete of canal floors, bottom heaves in quarries; and long-term movement of walls of unsupported excavations [1]. In many cases, the resulting defects can cause severe damage on underground structures that requires costly remedial and maintenance works [1].

The time-dependent deformation behaviour of rocks in Southern Ontario was extensively investigated during the past decades [2]-[9]. Considering the osmosis and diffusion as a mechanism of swelling, these investigations were mainly based on measuring the swell deformation of intact rock specimens submerged in water with variable confining pressures and variable salinity of the ambient water. However, present-day tunnel drilling technologies such as micro-tunnelling and horizontal direction drilling involve fluids such as bentonite slurry and synthetic polymers solutions during the drilling process, which may influence the strength and time-dependent deformation behaviour of rock in the vicinity of the tunnel annulus. Bearing this in mind, it is quite indispensable to investigate the influence of these drilling fluids on the strength and time-dependent deformation behaviour of rocks in this region, and that research is ongoing at Western University. However, the research preceded with a comprehensive literature review which resulted in a compilation of available properties data obtained from tests performed on the intact rock exposed only to water.

Therefore, this paper presents a compilation of a number of in-situ stress measurements, strength and stiffness measurements, time-dependent deformation measurements, and some dynamic properties measurements of different rock formations in Southern Ontario and the neighbouring regions. The objective is that the presented data serve as initial source of information for any prospective study of the geo-mechanical properties of the rocks in these specified regions. Figure 1 displays the locations of the sites from where data were compiled.

\section{Summary of Compiled Measurements}

\subsection{In-Situ Horizontal Stresses}

The available published values and directions of the in-situ horizontal stresses measured at different locations in Southern Ontario and the neighbouring regions were summarized and presented in Table 1. The presented data were compiled from sites where different measuring techniques were used to evaluate the in-situ stresses at variable depths and diversity of rock formations specifically in Southern Ontario and the surrounding regions (i.e. New York, Ohio, Michigan, Indiana, Illinois, Wisconsin, and Minnesota). In general, one of the earliest attempts to measure the in situ stresses in rocks was made by Hast in the 1950's in Scandinavia as described in [11]. This attempt was followed by numerous studies that resulted in developing several methods to measure the in-situ stresses in different locations all over the world, many of which were in Southern Ontario. The most commonly methods to measure the initial horizontal in-situ stresses in rocks are: 1) the hydraulic fracturing (hydro-fracturing test); 2) the over-coring technique with U.S. Bureau Mines probe (USBM); and 3) the under-coring technique with electrical strain gauges affixed in the borehole under consideration.

The hydraulic fracturing test consists essentially of sealing off a section of a borehole and injecting a fluid into the interval, inducing a fracture in the surrounding rock. The orientation of the resulting fracture and the pressures required to maintain the fracture are incorporated in an analysis to determine the in-situ stresses [12] [13]. The over-coring technique with (USBM) probe consists of drilling a hole to the required depth and then, from the bottom of this hole, a pilot hole of $38 \mathrm{~mm}$ diameter is drilled and the (USBM) probe is fixed in that hole. Then, the pilot hole is over-cored by employing a large diameter core bit to separate the rock core cylindercontaining the probe from in-situ. Later, the rock core cylinder is removed from the ground and tested in a hy- 


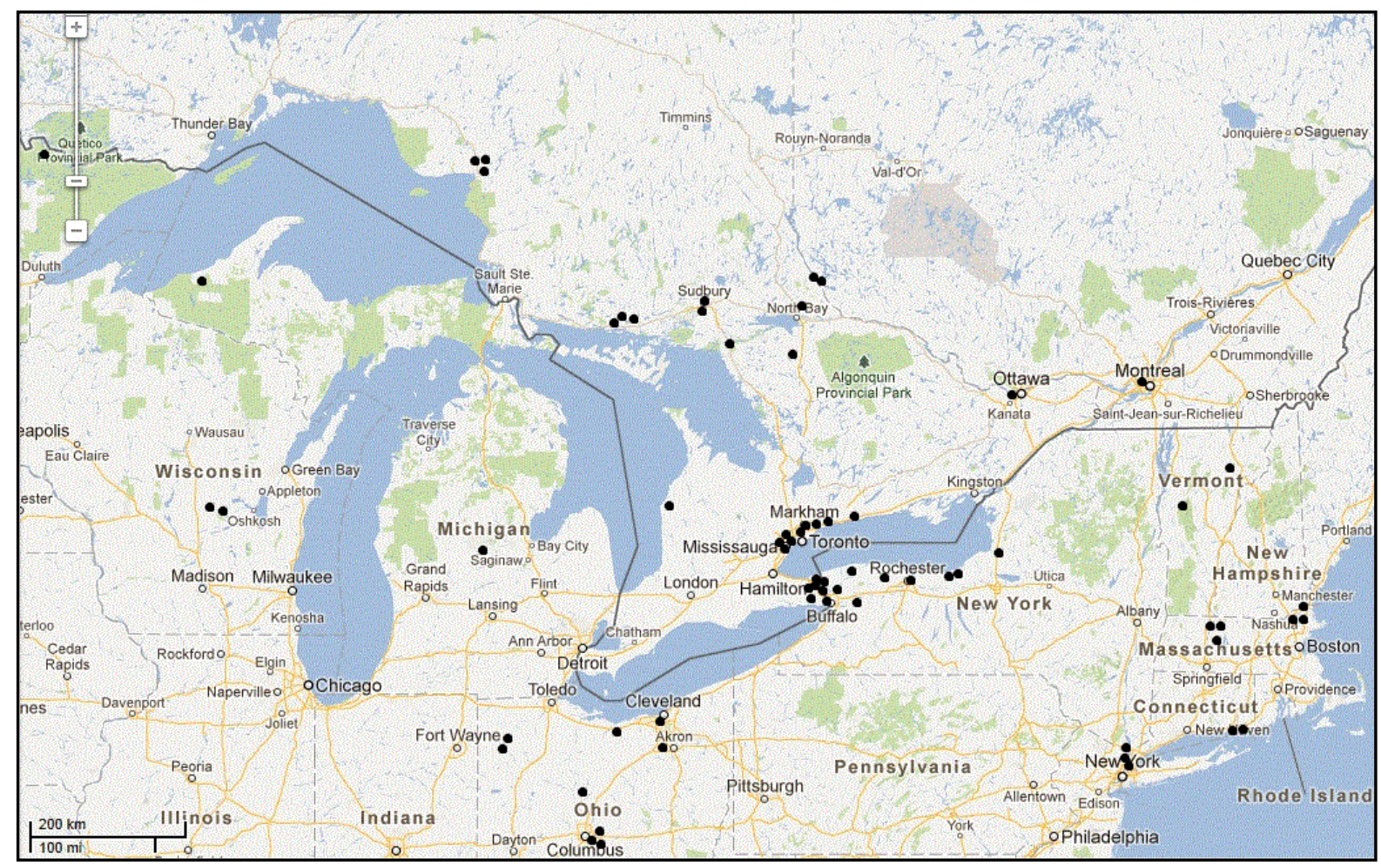

Figure 1. Locations of geo-mechanical data measurements [10].

draulic chamber to determine the modulus of elasticity and to calculate the in-situ horizontal stress using elastic theory relationships [13]. The under-coring technique employs a package of electrical strain gauges, which is affixed to the base of the borehole. The waterproof electrical package and connections are sealed in a cylindrical form of plastic, and are affixed with quick setting epoxy at the bottom of the borehole. The deformation measurements of the borehole are taken before and after extending the core bit beyond the base of the borehole which under-cores the electrical strain gauges [13].

From the summarized data presented in Table 1, the value of the initial in-situ horizontal stress in rock formations of Southern Ontario and the neighbouring regions varies from a relatively small amount ( $<1 \mathrm{MPa})$ for sandstone in Ohio [13] [14] to a considerably high amount (>80 MPa) for sandstone in Michigan [15]. The high variation of the measured in-situ stress in rocks depends on the rock formation, type, depth and interbedded layers in the rock mass where stress measurements were taken. For example, the Georgian Bay shales in Toronto, Ontario possess an initial in-situ horizontal stress of a considerably high value of 1.25 - 9.5 MPa in the major horizontal stress direction and 0.86 - 6.32 MPa in the minor horizontal stress direction at depth of 6.0 - $18.2 \mathrm{~m}$ [2] [3]. The Queenston shale from the Niagara Falls area, Ontario, exhibits an initial in-situ horizontal stresses of 14.3 - 17.1 MPa in the major horizontal stress direction and 8.6 - 11.3 MPa in the minor horizontal stress direction at depth of 93.9 - $123.8 \mathrm{~m}$ [16]. In addition, shale in Ohio, at 10.3 - $18.6 \mathrm{~m}$ depth, possesses comparatively high in-situ horizontal stresses of 5.56 - 38.13 MPa and 4.69 - 32.41 MPa in the major and minor in-situ horizontal stress directions, respectively [13]. In the presented data, the highest measured in-situ horizontal stresses in shale of North America were recorded in Michigan, where the stress measurements were taken at overwhelming depths that exceeded $5100 \mathrm{~m}$. The measured in-situ horizontal stresses in shale of Michigan at that depth were 135.0 MPa and 95.0 MPa in the major and minor in-situ horizontal stress directions, respectively [17].

On the other hand, sandstone of Elliot Lake, Ontario, at $427.0 \mathrm{~m}$ depth, exhibits an in-situ horizontal stress of 35.37 MPa and 24.13 MPa in the major and minor in-situ horizontal stress direction, respectively [18], while for similar depths in New York State the in-situ horizontal stresses in the sandstone were varying from 10.17 MPa in the minor in-situ horizontal stress direction to $15.69 \mathrm{MPa}$ in the major in-situ horizontal stress direction [19]. In Michigan, the in-situ horizontal stresses were measured at $3660 \mathrm{~m}$ deep in the sandstone layer and were found 
as high as 90.0 MPa and 67.0 MPa in the major and minor in-situ horizontal stress directions, respectively [15].

The limestone in Kincardine, Ontario and the limestone in Barberton, Ohio exhibits considerably high in-situ horizontal stresses of 44.7 MPa and 23.0 MPa in the major and in the minor in-situ horizontal stress directions, respectively, at depths of around $700 \mathrm{~m}$ [20] [21]. Similarly, the measured in-situ horizontal stresses at 341 - 420 $\mathrm{m}$ depth in the granite layer in Wawa, Ontario and in Manitoba were as high as $60.0 \mathrm{MPa}$ in the major in-situ horizontal stress direction and 40.0 MPa in the minor in-situ horizontal stress direction [13] [22] [23]. Although the in-situ vertical stresses from the overburden are not presented here in the compiled data, it could be perceived that in general, the rock formations in Ontario and neighbouring regions are subjected to a considerably high in-situ horizontal stresses.

Lo [1] analyzed natural geological features, such as: faulting; folding and buckling or pop-up of surface rock strata; distress in shallow and deep excavation, such as heaves in the Dufferin quarry in Milton; jamming of wheel pit, bending and buckling of steel beams structures of hydro-electric power plants; and crushing and spalling of arch and floor heave of the hydro tunnels in the Niagara area and Chippawa Canal in Ontario. Based on these analyses, it was suggested by Lo [1] that these observations were evidence of high in-situ horizontal stresses that resulted from the current movement of continental drift according to tectonic theory, and not due to the past overburden load during glaciation ages [1]. From the recorded in-situ stress measurements and the observation of natural phenomena, it was proposed that the belt of high horizontal stresses stretches from Rochester in New York State westward through Niagara Falls, turning northeast around Lake Ontario following the lake shore line and extending at least as far east as Wesleyville, Ontario [1].

The high in-situ horizontal stresses in rocks are a general phenomenon that exists in many regions in North America and the world. However, the rock formations in Southern Ontario and the neighbouring states, in specific, exhibit a considerably high in-situ horizontal stresses. These high in-situ horizontal stresses, after their relief, might be of significant influence on the time-dependent deformation characteristics of these rocks, which in turn might cause serious damages to the constructed underground structures.

\subsection{Intact Rock Strength and Stiffness Properties}

The values of the tensile strength, compressive strength, elastic (Young's) modulus and Poisson's ratio of different rock formations in Southern Ontario and the neighbouring regions are summarized and presented in Table 2. The presented data were compiled from available relevant literature.

The tensile strength of intact rock is measured in a laboratory either directly with the direct tension test or indirectly with the indirect tension test, which is commonly known as a Brazilian test or a split test. In the direct tension test, a cylindrical rock specimen is subjected to a direct uniaxial tensile stress along its longitudinal axis until failure. In the Brazilian test, the indirect tensile strength of the rock is measured on disc specimens by applying a compressive stress across the disc perimeter until failure. The failure occurs along the diameter of the disc specimen in a biaxial state of stress where one principal stress is highly compressive. In general, the indirect tensile strength of rock measured from the Brazilian test is higher than the tensile strength of the same rock measured from the direct tension test.

The compressive strength, elastic (Young's) modulus, and Poisson's ratio of intact rocks are all measured in a laboratory either through a uniaxial compression test or a triaxial compression test. In the uniaxial compression test, a cylindrical rock specimen is subjected to a compressive stress along its longitudinal axis until failure occurs, while in the triaxial compression test, failure is similarly induced when the cylindrical rock specimen is subjected to a specific value of confining pressure. In both tests, electronic strain gauges are affixed onto the specimen, parallel and perpendicular to the longitudinal axis of the specimen, to measure the axial and diametric deformations during the tests. The elastic theory relationships are then used to calculate the elastic modulus and Poisson's ratio.

The strength and stiffness characteristics of intact rock specimens extracted from different rock formations in Southern Ontario and the neighbouring regions were extensively investigated over the past decades [4] [18] [24]-[26]. However, the in-situ medium (i.e. the rock mass) comprises of intact rock blocks that are separated by discontinuities such as joints, fissures and faults [27]. These discontinuities have a great influence on the overall strength characteristics of the rock mass, and therefore they have to be prudently considered in evaluating the overall strength of the rock mass. The rock mass modulus can be measured in-situ by recording the deformation in the diameter of a pre-drilled monitoring hole through the rock mass while extending the tunnel excavations. 
The deformation is recorded using an extensometer probe that is affixed at the bottom of the monitoring hole. Another field test method was developed in 1987 by Lo, Yung and Lukajic [25] to measure the rock mass modulus at the surface of the excavated rock. In principle, the developed method consisted of measuring the variation in the diametric distance between each opposite pair of pre-glued props into pre-drilled holes from the surface of the rock layer, in a rosette pattern, while extending a central hole into the rock layer from the surface. The elastic theory was then used to calculate the rock mass modulus [25]. The developed method was used to measure the rock mass modulus of the limestone layer at the intake and discharge tunnels of Darlington Generating Station, east of Toronto. The values of the measure rock modulus from this method were consistent with those evaluated from extensometer measurements in the tunnels.

As mentioned before, the strength data presented in Table 2 were assembled from laboratory tests performed on intact rock specimens of samples extracted from variable depths and diversity of rock formations in the concerned area. In general, the dolomitic limestone of Lockport formation possesses the highest uniaxial compression strength of 199 - $246 \mathrm{MPa}$ among all other rocks in Southern Ontario [5]. The sandstone of Whirlpool formation and the dolostone of Lockport formation exhibit uniaxial compression strength of $190 \mathrm{MPa}$ and $200 \mathrm{MPa}$, respectively [3]. The black shale of Collingwood formation and the Rochester shale exhibit a high uniaxial compression strength of $80-85 \mathrm{MPa}$ in contrast to other shales in Southern Ontario, such as Georgian Bay, Grimsby, Power Glen, Blue Mountain, and Queenston in which the uniaxial compression strength ranges between 20 - $30 \mathrm{MPa}$ [3]. Moreover, most of the sedimentary rocks of Southern Ontario possess anisotropy in their uniaxial compression strength, with respect to the bedding planes.

As can be seen from Table 2, the available data of the tensile strength of rocks in the specified area are very limited. However, it is reported that the tensile strength of Queenston shale from different sites in Southern Ontario varies between $1 \mathrm{MPa}$ to $15 \mathrm{MPa}$ in contrast to Sherman Fall shale where the tensile strength is $0.1-3 \mathrm{MPa}$ [20]. It is reported that the dolostone and mudstone of De Cew formation possess a tensile strength of $5 \mathrm{MPa}$ [20].

The elastic modulus of siderite and tuff in Wawa, Ontario was reported as 67.6 - $118.0 \mathrm{GPa}$ and 68.3 - 115.8 GPa [28], respectively. The quartzite and sandstone of Elliot Lake, Ontario possess an elastic modulus of 80.0 GPa and 76.0 GPa respectively [18] [29], while the shales, in general, possess an average elastic modulus of 10.0 GPa [2]-[4] [7] [8] [20]. On the other hand, the Poisson's ratio of rocks in Southern Ontario was ranging from 0.13 for Georgian Bay shale [5] to 0.6 for argillaceous limestone of Cobourg formation [20]. Moreover, most of the sedimentary rocks of Southern Ontario possess anisotropy in their strength and stiffness properties, with respect to the bedding planes.

As stated earlier, the presented data in Table 2 are based on laboratory tests that were performed on freshly recovered intact rocks from the ground. In practice, the rocks at the surfaces of the underground tunnel excavations are actually exposed either to water or other drilling fluids, such as bentonite slurry or synthetic polymers solutions as part of the construction process for the buried infrastructures. These drilling fluids are used as lubricant to facilitate the drilling process through the rock mass or to convey the excavated rocks. As mentioned before, there is lack of information with regard to the influence of the exposure of rocks to the drilling fluids near the surfaces of excavation on the strength characteristics of these rocks, therefore, the influence of these drilling fluids on the strength and stiffness characteristics of rocks in Southern Ontario is under ongoing investigation at Western University.

\subsection{Intact Rock Time-Dependent Deformation Properties}

The swelling potential of rocks is an important factor in designing underground structures and has a significant influence on the stability of these structures. As proposed by Lo, Palmer and Quigly [7], the swelling potential in the swelling rocks can be defined as the swelling strain per log cycle of time and it can be calculated through the free swell test. In the free swell test, the intact rock specimen is submerged in water and allowed to expand freely in all directions while the swelling strain is measured in three orthogonal directions [7]. The horizontal swell strain is measured in the direction parallel to the bedding planes of the rock sample, while the vertical swell strain is measured in the direction perpendicular to the bedding planes. The swelling potential values measured in the vertical and horizontal directions with respect to the bedding planes of different rock formations in Southern Ontario and the neighbouring regions are presented in Table 2.

As can be seen in Table 2, most of the shaly rock formations exhibit anisotropy in their swelling behaviour in 
the direction parallel and perpendicular to the bedding planes [6]-[8]. For example, the Queenston shale from Niagara Falls exhibits swelling potential of $0.37 \%-0.54 \%$ in the vertical direction and $0.22 \%-0.34 \%$ in the horizontal direction [6]. The Georgian Bay shale from different sites in Southern Ontario indicates swelling potential of $0.2 \%-0.22 \%$ in the vertical direction and $0.03 \%-0.14 \%$ in the horizontal direction [7]. The Rochester shale exhibits relatively small swelling potential averaging $0.16 \%$ and $0.07 \%$ in the vertical and horizontal directions, respectively [7]. In general, the limestone displays zero swelling potential due to their high calcite content, however, some shaly limestone such as Gasport shaly limestone exhibits swelling potential of $0.08 \%$ in both horizontal and vertical directions [7].

Lee and Lo [8] investigated the swelling mechanism of shales in Southern Ontario by submerging the shale specimens in water with varying salt concentrations. Based on the results of their investigations, they suggested that the swelling mechanism of shales in this region was based on the process of osmosis and diffusion which occurred between the rock pore water and the ambient fluid. It was concluded that swelling occurs if three conditions are met: $i$ ) relief of initial stress, ii) accessibility of water and iii) an outward salt concentration gradient from pore fluid exists. They assumed that swelling may or may not occur if only one or two of these conditions are met. Although the swelling behaviour of shales in Southern Ontario was extensively investigated in water [3] [6]-[8], there is lack of information with respect to swelling behaviour of these shales in drilling fluids, such as bentonite slurry and synthetic polymers solutions.

\subsection{Dynamic Properties of Rocks}

The compressional wave velocity, shear wave velocity, dynamic Poisson's ratio and dynamic modulus of different rock formations in Southern Ontario were compiled and presented in Table 3. The compressional wave and the shear wave velocities were measured on intact rock specimens and the dynamic Poisson's ratio and the dynamic modulus were calculated using the fundamental equations for torsional vibration [5] [6] [25].

In general, the presented data revealed anisotropy in the dynamic behaviour of the sedimentary rocks in Southern Ontario. For the same rock formation, the value of the dynamic modulus in the direction parallel to the bedding planes is higher than that in the direction perpendicular to the bedding planes. It should be noted that the presented dynamic properties are obtained for intact rock specimens. However, the effects of saturation in drilling fluids such as bentonite slurry and synthetic polymers solution on the dynamic properties of rocks still need to be investigated.

\section{Summary and Conclusions}

A comprehensive review of the available literature on the geo-mechanical properties of rock formations in Southern Ontario and the neighbouring regions (New York, Pennsylvania, Ohio, Michigan, Indiana, Illinois, Wisconsin, and Minnesota) was performed. The available data on the measured in-situ stresses and the direction of major principal stress, strength and stiffness properties, time-dependent deformation properties, and dynamic properties of different rocks from that literature were compiled. The presented data can serve as a preliminary source of information for any prospective study of the geo-mechanical properties of the rocks in Southern Ontario and the neighbouring regions.

From this compiled data, the following conclusions can be drawn:

1) The value of the initial in-situ horizontal stress in rock formations of Southern Ontario and the neighbouring regions varies from a relatively small amount, $<1 \mathrm{MPa}$, to a considerably high amount, $>100 \mathrm{MPa}$, depending on the rock formation, depth and inter-bedded layers in the rock mass. For depths up to $30 \mathrm{~m}$ where most of the engineering projects are located, the in-situ horizontal stresses in rocks of Southern Ontario and the neighbouring regions are ranging between $-4.87 \mathrm{MPa}$ to $38.13 \mathrm{MPa}$, while for depths greater than $30 \mathrm{~m}$ and up to $1000 \mathrm{~m}$ where the mining projects are located, the in-situ horizontal stresses are ranging between 1.59 MPa to 85.7 MPa. Moreover, the in-situ horizontal stresses are considerably high for depths greater than $1000 \mathrm{~m}$ where the hydrocarbons projects are located, ranging from 42.0 MPa to as high as 135.0 MPa.

2) Among shales of Southern Ontario and the neighbouring regions, the Queenston shale of Niagara Falls region exhibits highest swelling potential of $0.37 \%-0.54 \%$ in the vertical direction and $0.22 \%-0.34 \%$ in the horizontal direction, with respect to the bedding planes.

3) The sedimentary rocks and shales in particular, possess considerable anisotropy in their strength, time-dependent deformation and dynamic properties, relative to the bedding planes. 
4) Although the swelling behaviour of rocks in Southern Ontario and the neighboring regions was extensively investigated using water as an ambient solution, there is a lack of information with respect to the time-dependent deformation behaviour of these rocks in fluids such as bentonite slurry and synthetic polymers solution. For most of the tunnel drilling process through the rock mass, other than blasting, fluids such as bentonite slurry and synthetic polymers solutions are used either to convey the excavated materials or to lubricate the annulus of the excavated tunnel. Therefore, it is quite indispensable to investigate the influence of these fluids on the strength, time-dependent deformation and dynamic characteristics of these rocks, which is the topic of the ongoing research at Western University.

\section{Acknowledgements}

This Research is being performed under the umbrella of the Geotechnical Research Centre (GRC) in Western University. The authors would like to thank Ward \& Bark Microtunnelling Ltd. For their financial support, the authors also would like to thank Dr. K. Y. Lo for his valuable guidance.

\section{References}

[1] Lo, K.Y. (1978) Regional Distribution of in Situ Horizontal Stresses in Rocks of Southern Ontario. Canadian Geotechnical Journal, 15, 371-381. http://dx.doi.org/10.1139/t78-034

[2] Lo, K. Y., and Yuen, C.M.K. (1981) Design of Tunnel Lining in Rock for Long Term Time Effects. Canadia Geotechnical Journal, 18, 24-39. http://dx.doi.org/10.1139/t81-004

[3] Lo, K.Y. (1089) Recent Advances in Design and Evaluation of Performance of Underground Structures in Rocks. Tunnelling and Underground Space Technology, 4, 171-183. http://dx.doi.org/10.1016/0886-7798(89)90050-3

[4] Lo, K.Y., Cooke, B.H. and Dunbar, D.D. (1987) Design of Buried Structures in Squeezing Rock in Toronto, Canada. Canadian Geotechnical Journal, 24, 232-241. http://dx.doi.org/10.1139/t87-028

[5] Lo, K.Y. and Hori, M. (1979) Deformation and Strength Properties of Some Rocks in Southern Ontario. Canadian Geotechnical Journal, 16, 108-120. http://dx.doi.org/10.1139/t79-010

[6] Lo, K.Y. and Lee, Y.N. (1990) Time-Dependent Deformation Behaviour of Queenston Shales. Canadian Geotechnical Journal, 27, 461-471. http://dx.doi.org/10.1139/t90-061

[7] Lo, K.Y., Palmer, J. H. L. and Quigly, R.M. (1978) Time-Dependent Deformation of Shaly Rocks in Southern Ontario. Canadian Geotechnical Journal, 15, 537-547. http://dx.doi.org/10.1139/t78-057

[8] Lee, Y.N. and Lo, K.Y. (1993) The Swelling Mechanism of Queenston Shale. Canadian Tunnelling, 75-97.

[9] Hefney, A., Lo, K.Y. and Huang, J.A. (1996) Modelling of Long-Term Time-Dependent Deformation and Stress Dependency of Queenston Shales. Tunnelling Association of Canada Annual Publication, 115-146.

[10] Map of Southern Ontario and Neighbouring Regions, Google Maps. https://maps.google.ca

[11] Terzaghi, K. (1962) Measurement of Stresses in Rock. Géotechnique, 12, 105-124. http://www.icevirtuallibrary.com/content/article/10.1680/geot.1962.12.2.105 http://dx.doi.org/10.1680/geot.1962.12.2.105

[12] Von Schonfeldt, H. and Fairhurst, C. (1972) Field Experiments on Hydraulic Fracturing. American Institute of Mining Engineers, 253, 69-77.

[13] Lindner, E.N. and Halpern, J.A. (1978) In-Situ Stress in North America: A Compilation. International Journal of Rock Mechanics and Mining Sciences and Geomechanics Abstracts, 15, 183-203. http://dx.doi.org/10.1016/0148-9062(78)91225-1

[14] Rough, R.L. and Lambert, W.G. (1971) In-Situ Strain Orientations: A Comparison of Three Measuring Techniques. Report of Investigation, 7575, US Department of Interior, Bureau of Mines, USA. http://books.google.ca/books?id=DgXoGQAACAAJ

[15] Haimson, B.C. (1976) The Hydrofracturing Stress Measuring Technique-Method and Recent Field Results in the US. The Proceedings of the International Society of Rock Mechanics Symposium, Sydney, 23-30.

[16] Lo, K.Y. and Hefney, A. (1993) The Evaluation of In-Situ Stresses by Hydraulic Fracturing Tests in Anisotropic Rocks with Mixed-Mode Fractures. Canadian Tunnelling, 59-73.

[17] Haimson, B. and Fairhurst, C. (1970) In-Situ Stress Determination at Great Depth by Means of Hydraulic Fracturing. Rock Mechanics-Theory and Practice. The Proceedings of the 11th Symposium on Rock Mechanics, 16-19 June 1969, Berkeley, 559-584.

[18] van Heerden, W.L. and Grant, F. (1967) A Comparison of Two Methods for Measuring Stress in Rock. International Journal of Rock Mechanics and Mining Sciences \& Geomechanics Abstracts, 4, 367-382. 
http://dx.doi.org/10.1016/0148-9062(67)90028-9

[19] Haimson, B. and Stahl, E.J. (1969) Hydraulic Fracturing and the Extraction of Minerals through Wells. The Proceedings of the 3rd Symposium on Salt, Northern Ohio Geological Society, Cleveland, 421-432.

[20] Lam, T., Engelder, T., Leech, R.E.J. and Jensen, M. (2011) Regional Geomechanics-Southern Ontario. Nuclear Waste Management Organization and AECOM Canada Ltd., Technical Report No. NWMO DGR-TR-2011-13.

[21] Obert, L.A. (1962) In-situ Determination of Stress in Rock. Mining Engineering, 14, 51-58.

[22] Buchbinder, G.G.R., Nyland, E. and Blanchard, J.E. (1965) Measurement of Stress in Bore-Holes, in Drilling for Scientific Purposes. Proceedings of the International Upper Mantle Symposium, Ottawa, 2-3 September 1965, 85-93.

[23] Fairhurst, C. (2004) Nuclear Waste Disposal and Rock Mechanics: Contributions of the Underground Research Laboratory (URL), Pinawa, Manitoba, Canada. International Journal of Rock Mechanics and Mining Sciences, 41, 12211227. http://dx.doi.org/10.1016/j.ijrmms.2004.09.001

[24] Palmer, H.L. and Lo, K.Y. (1976) In Situ Measurements in Some near Surface Rock Formation-Thorold, Ontario. Canadian Geotechnical Journal, 13, 1-7. http://dx.doi.org/10.1139/t76-001

[25] Lo, K.Y., Yung, C.B. and Lukajic, B. (1987) A Field Method for the Determination of Rock-Mass Modulus. Canadian Geotechnical Journal, 24, 406-413. http://dx.doi.org/10.1139/t87-051

[26] Hefney, A. and Lo, K.Y. (1995) Interpretation of Initial Stresses from Hydraulic Fracturing Tests at AECL's Underground Research Laboratory, Manitoba. Tunnelling Association of Canada Annual Publication, 123-134.

[27] Hoek, E. (2001) Big Tunnels in Bad Rocks-2000 Terzaghi Lecture. American Society of Civil Engineers Journal of Geotechnical and Geoenvironmental Engineering, 127, 726-740.

http://www.rocscience.com/hoek/references/H2001b.PDF

[28] Herget, G. (1973) Variation of Rock Stresses with Depth at a Canadian Iron Mine. International Journal of Rock Mechanics and Mining Sciences \& Geomechanics Abstracts, 10, 37-51. http://dx.doi.org/10.1016/0148-9062(73)90058-2

[29] Eisbacher, G.H. and Bielenstein, H.U. (1971) Elastic Strain Recovery in Proterozonic Rocks Near Elliot Lake, Ontario. Journal of Geophysical Research, 76, 2012-2021. http://dx.doi.org/10.1029/JB076i008p02012

[30] Canada. Mines Branch, Coates, D.F., Grant, F. and Heerden, W.L. (1968) Stress Measurements at Elliot Lake. Canada Mines Branch Reprint Series, R. Duhamel, 603-613. http://books.google.ca/books?id=13N_tgAACAAJ

[31] Franklin, J.A. and Hungr, O. (1978) Rock Stresses in Canada: Their Relevance to Engineering Projects. Rock Mechanics, 6, 25-46.

[32] Lo, K.Y., Lukajic, B., Yuen, C.M.K. and Hori, M. (1982) In-Situ Stresses in a Rock Overhang at the Ontario Power Generating Station, Niagara Falls. Proceedings of the 23rd Symposium on Rock Mechanics, Berkeley, 25-27 August 1982, 343-352.

[33] Moruzi, G.A. (1968) Application of Rock Mechanics in Mine Planning and Ground Control. Current Rock Mechanics, Chap. 3, Studies at Falconbridge. Canadian Mining Journal, 89, 12-15.

[34] Metaltech Inspection Ltd. (1970) Rapport D’Investigation, Measure Des Constraintes En Place. Contract No. 1009-61, Commission Hydro-Electrique du Quebec.

[35] Benson, R.P., Kierans, T.W. and Sigvaldason, O.T. (1970) In-Situ and Induced Stresses at the Churchill Falls Underground Powerhouse, Labrador. Proceedings of the 2nd Congress of the International Society for Rock Mechanics, 4, 821-832.

[36] Hefney, A. and Lo, K.Y. (1992) The Interpretation of Horizontal and Mixed-Mode Fractures in Hydraulic Fracturing Test in Rocks. Canadian Geotechnical Journal, 29, 902-917. http://dx.doi.org/10.1139/t92-102

[37] Fairhurst, C. (2003) Stress Estimation in Rock: A Brief History and Review. International Journal of Rock Mechanics and Mining Sciences, 40, 957-973. http://dx.doi.org/10.1016/j.ijrmms.2003.07.002

[38] Thompson, P.M. and Chandler, N.A. (2004) In-Situ Rock Stress Determinations in Deep Boreholes at the Underground Research Laboratory. International Journal of Rock Mechanics and Mining Sciences, 41, 1305-1316. http://dx.doi.org/10.1016/j.ijrmms.2004.09.003

[39] Sbar, M.L. and Sykes, L.R. (1973) Contemporary Compressive Stress and Seismicity in Eastern North America: An Example of Intra-Plate Tectonics. Geological Society of America Bulletin, 84, 1861-1882. http://dx.doi.org/10.1130/0016-7606(1973)84<1861:CCSASI>2.0.CO;2

[40] Sellers, J.B. (1969) Strain Relief Overcoring to Measure in-Situ Stresses. Niagara Falls Project, Corps of Engineers, Buffalo District.

[41] Hooker, V.E. and Johnson, C.F. (1977) In-Situ Stresses along the Appalachian Piedmont. Proceedings of the 4th Canadian Symposium on Rock Mechanics, Ottawa, 29-30 March 1967, 137-155.

[42] Goldberg, Z. and Dunnicliff and Associates (1976) Report on in-Situ Stress Measurements, Genessee River Interceptor, Southwest Rochester, NewYork, File No. 1661, Firelands Sewer and Water Construction Company, New York. 
[43] Dames and Moore Consultants (1973) In-Situ Stress Measurement. Report of Investigation, North Anna Power Project.

[44] Dames and Moore Consultants (1974) Geological Report. Report No. 4852-002-18, Limerick Generating Station.

[45] Bonnechere, F. (1969) A Comparative Field Study of Rock Stress Determination Techniques. Missouri River Division, Report No. 68101, Corps of Engineers, Omaha.

[46] Foundation Sciences Incorporation (1971) Bear Swamp Project-Rock Mechanics Studies. New England Power Service Company, Westborough.

[47] Lo, K.Y. and Lukajic, B. (1984) Predicted and Measured Stresses and Displacements around the Darlington Intake Tunnel. Canadian Geotechnical Journal, 21, 147-165. http://dx.doi.org/10.1139/t84-012

Table 1. In-Situ stresses in rocks.

\begin{tabular}{|c|c|c|c|c|c|c|c|c|c|}
\hline Province/State/City & Project & $\begin{array}{l}\text { Rock } \\
\text { Formation }\end{array}$ & Rock Type & Depth (m) & $\begin{array}{l}\text { Horizontal } \\
\text { Minor stress } \\
\text { (MPa) }\end{array}$ & $\begin{array}{l}\text { Horizontal } \\
\text { Major stress } \\
\quad \text { (MPa) }\end{array}$ & $\begin{array}{l}\text { Direction of } \\
\text { Major } \\
\text { Horizontal } \\
\text { Stress }\end{array}$ & $\begin{array}{l}\text { Method } \\
\text { Used }\end{array}$ & $\begin{array}{l}\text { Source } \\
\text { of Data }\end{array}$ \\
\hline $\begin{array}{l}\text { Ontario/Dufferin } \\
\text { Creek }\end{array}$ & $\begin{array}{l}\text { Outcrop in Duffin } \\
\text { Creek, Ontario }\end{array}$ & - & Shale & $9.1-15.2$ & 6.9 & - & - & USBM & [1] \\
\hline \multirow[t]{2}{*}{ Ontario/Elliot Lake } & $\begin{array}{l}\text { Mine in Elliot } \\
\text { Lake, Ontario }\end{array}$ & - & Quartzite & $390.0-415.0$ & $21.4-44.1$ & - & - & - & [30] \\
\hline & & & Diabase & 256 & $15.2-41.4$ & & & & \\
\hline Ontario/Elliot Lake & $\begin{array}{l}\text { Mine in Elliot } \\
\text { Lake, Ontario }\end{array}$ & - & $\begin{array}{l}\text { Sandstone/ } \\
\text { Quartzite }\end{array}$ & $204.8-701.0$ & $17.24-22.06$ & $20.69-36.54$ & East & OC & [29] \\
\hline Ontario/Elliot Lake & $\begin{array}{l}\text { Mine in Elliot } \\
\text { Lake, Ontario }\end{array}$ & - & $\begin{array}{l}\text { Sandstone/ } \\
\text { Quartzite }\end{array}$ & 427 & 24.13 & 35.37 & - & USBM & [18] \\
\hline Ontario/Kincardine & $\begin{array}{c}\text { Bruce Nuclear } \\
\text { Repository Site in } \\
\text { Kincardine, } \\
\text { Ontario }\end{array}$ & Cobourg & limestone & 670 & 23 & 44.7 & $\mathrm{~N} 75^{\circ} \mathrm{E}$ & $\mathrm{HF}$ & [20] \\
\hline Ontario/Mississauga & $\begin{array}{c}\text { Heart Lake Tunnel } \\
\text { in Mississauga, } \\
\text { Ontario }\end{array}$ & $\begin{array}{l}\text { Georgian } \\
\text { Bay }\end{array}$ & Shale & $6.0-18.2$ & $0.86-6.32$ & $1.25-9.5$ & $\begin{array}{l}\mathrm{N} 10^{\circ}-48^{\circ} \mathrm{E} \\
\mathrm{N} 2^{\circ}-86^{\circ} \mathrm{W}\end{array}$ & USBM & [2] \\
\hline Ontario/Mississauga & $\begin{array}{l}\text { Outcrop in } \\
\text { Mississauga, } \\
\text { Ontario }\end{array}$ & - & Shale & $9.1-15.2$ & 7.6 & - & - & - & [1] \\
\hline Ontario/Niagara Falls & $\begin{array}{l}\text { SABNGS No3 in } \\
\text { Niagara Falls, } \\
\text { Ontario }\end{array}$ & Queenston & Shale & $93.9-123.8$ & $8.6-11.3$ & $14.3-17.1$ & - & MSP & [16] \\
\hline Ontario/Ottawa & $\begin{array}{c}\text { Outcrop in Ottawa, } \\
\text { Ontario }\end{array}$ & - & - & 13.7 & 2.6 & - & - & USBM & [31] \\
\hline Ontario/Port Hope & $\begin{array}{c}\text { Wesleyville } \\
\text { Generating } \\
\text { Station, Port Hope, } \\
\text { Ontario }\end{array}$ & Trenton & Limestone & 36.6 & 9.7 & $8.0-13.0$ & $\mathrm{~N} 15^{\circ} \mathrm{W}$ & - & [1] \\
\hline Ontario/Scarborough & $\begin{array}{l}\text { Tunnel in } \\
\text { Scarborough, } \\
\text { Ontario }\end{array}$ & - & Shale & 70.1 & 1.59 & 1.69 & $\mathrm{~N} 90^{\circ} \mathrm{E}$ & USBM & [31] \\
\hline Ontario/Thorold & $\begin{array}{l}\text { Thorold Tunnel In } \\
\text { Thorold, Ontario }\end{array}$ & Gasport & Shaly limestone & 18.3 & $6.63-12.7$ & $8.14-14.69$ & $\mathrm{~N} 60^{\circ} \mathrm{E}$ & USBM & $\begin{array}{c}{[1][7]} \\
{[32]}\end{array}$ \\
\hline
\end{tabular}




\section{Continued}

\begin{tabular}{|c|c|c|c|c|c|c|c|c|c|}
\hline \multirow[t]{5}{*}{ Ontario/Thorold } & \multirow[t]{5}{*}{$\begin{array}{l}\text { Thorold Tunnel In } \\
\text { Thorold, Ontario }\end{array}$} & Gasport & Dolomite & $12.7-16.19$ & $5.23-12.104$ & $6.633-13.0^{I}$ & \multicolumn{2}{|c|}{$\begin{array}{l}\mathrm{N} 27^{\circ}-88^{\circ} \mathrm{W}, \text { USBM } \\
\quad \mathrm{N} 62^{\circ} \mathrm{E}\end{array}$} & \multirow[t]{5}{*}{$\begin{array}{r}{[1][7} \\
{[32]}\end{array}$} \\
\hline & & Gasport & Dolomitic limestone & 17.26 & $6.682-6.861$ & $6.861-8.99$ & $\mathrm{~N} 60^{\circ}-76^{\circ} \mathrm{E}$ & & \\
\hline & & Gasport & $\begin{array}{l}\text { Fossiliferous } \\
\text { limestone }\end{array}$ & 19.82 & 6.647 & 13.833 & $\mathrm{~N} 56^{\circ} \mathrm{E}$ & & \\
\hline & & Gasport & $\begin{array}{l}\text { Argillaceous } \\
\text { limestone }\end{array}$ & 24.7 & 6.848 & 10.513 & $\mathrm{~N} 60^{\circ} \mathrm{E}$ & & \\
\hline & & Gasport & $\begin{array}{l}\text { Limestone with } \\
\text { shaly interbeds }\end{array}$ & $74.7-299.5$ & $5.23-12.104$ & $6.633-13.0$ & $\begin{array}{l}\mathrm{N} 27^{\circ}-88^{\circ} \mathrm{W} \\
\mathrm{N} 62^{\circ} \mathrm{E}\end{array}$ & & \\
\hline \multirow[t]{5}{*}{ Ontario/Thorold } & \multirow[t]{5}{*}{$\begin{array}{l}\text { Thorold Tunnel in } \\
\text { Thorold, Ontario }\end{array}$} & \multirow{5}{*}{$\begin{array}{l}\text { Gasport } \\
\text { member of } \\
\text { Lockport } \\
\text { and Decew } \\
\text { formations }\end{array}$} & Dolomite & $41.7-53.1$ & $5.2-12.7$ & $6.6-13$ & $\begin{array}{l}\mathrm{N} 27^{\circ}-88^{\circ} \mathrm{W} \\
\mathrm{N} 62^{\circ} \mathrm{E}\end{array}$ & \multirow[t]{5}{*}{ USBM } & \multirow[t]{5}{*}{ [24] } \\
\hline & & & Dolomitic limestone & 56.6 & $5.2-6.6$ & $6.8-9.03$ & $\mathrm{~N} 76^{\circ} \mathrm{E}$ & & \\
\hline & & & Shaly limestone & $60.0-61.0$ & $11.0-11.2$ & 14.69 & $\mathrm{~N} 58^{\circ}-60^{\circ} \mathrm{E}$ & & \\
\hline & & & $\begin{array}{l}\text { Fossiliferous } \\
\text { limestone }\end{array}$ & 65 & 6.63 & 13.8 & $\mathrm{~N} 56^{\circ} \mathrm{E}$ & & \\
\hline & & & $\begin{array}{l}\text { Argillaceous } \\
\text { limestone }\end{array}$ & 81 & 6.83 & 10.5 & $\mathrm{~N} 60^{\circ} \mathrm{E}$ & & \\
\hline \multirow[t]{2}{*}{ Ontario/Thorold } & \multirow[t]{2}{*}{$\begin{array}{c}\text { Outcrop in } \\
\text { Thorold, Ontario }\end{array}$} & \multirow[t]{2}{*}{-} & Dolomite & $12.7-15.5$ & $5.21-12.07$ & $9.03-12.07$ & $\begin{array}{c}\mathrm{N} 27^{\circ}-\mathrm{W}, \mathrm{N} \\
88^{\circ} \mathrm{W}\end{array}$ & \multirow[t]{2}{*}{ OC } & \multirow[t]{2}{*}{ [13] } \\
\hline & & & Dolomitic limestone & $16.2-17.3$ & $6.59-6.66$ & $8.14-8.96$ & $\begin{array}{l}\mathrm{N} 62^{\circ} \mathrm{E} \\
\mathrm{N} 76^{\circ} \mathrm{E}\end{array}$ & & \\
\hline \multirow[t]{2}{*}{ Ontario/Thorold } & \multirow[t]{2}{*}{$\begin{array}{l}\text { Outcrop in } \\
\text { Thorold, Ontario }\end{array}$} & \multirow[t]{2}{*}{-} & Shaly limestone & $18.3-18.6$ & $11.03-11.17$ & 14.69 & $\begin{array}{l}\mathrm{N} 60^{\circ} \mathrm{E} \\
\mathrm{N} 58^{\circ} \mathrm{E}\end{array}$ & \multirow[t]{2}{*}{ OC } & \multirow[t]{2}{*}[13]{} \\
\hline & & & Limestone & $19.8-24.7$ & $6.63-6.83$ & 10.48 - 13.79 & $\begin{array}{l}\mathrm{N} 56^{\circ} \mathrm{E} \\
\mathrm{N} 60^{\circ} \mathrm{E}\end{array}$ & & \\
\hline Ontario/Wawa & $\begin{array}{l}\text { Mine in Wawa, } \\
\text { Ontario }\end{array}$ & - & Granite & 341.4 & 40 & 60 & - & - & [22] \\
\hline \multirow[t]{4}{*}{ Ontario/Wawa } & \multirow[t]{4}{*}{$\begin{array}{l}\text { Mine in Wawa, } \\
\text { Ontario }\end{array}$} & \multirow[t]{4}{*}{-} & Siderite & 365.8 & $20.06-34.27$ & $21.44-42.47$ & $\mathrm{~S} 47^{\circ}-63^{\circ} \mathrm{E}$ & \multirow[t]{4}{*}{$\mathrm{D}$} & \multirow[t]{4}{*}{ [28] } \\
\hline & & & Tuff & 478.5 & $27.65-34.06$ & $30.0-47.16$ & $\mathrm{~S} 42^{\circ}-71^{\circ} \mathrm{W}$ & & \\
\hline & & & Meta - diorite & 573 & 21.51 & 31.58 & $\mathrm{~S} 18^{\circ} \mathrm{E}$ & & \\
\hline & & & Chert & 573 & $16.62-21.37$ & $19.93-38.27$ & $\begin{array}{c}\mathrm{S} 44^{\circ} \mathrm{W}, \mathrm{N} \\
4^{\circ} \mathrm{W}\end{array}$ & & \\
\hline Ontario/Wawa & $\begin{array}{l}\text { Mine in Wawa, } \\
\text { Ontario }\end{array}$ & - & - & 332 & 27.9 & - & - & $\mathrm{D}$ & [31] \\
\hline Ontario/Darlington & $\begin{array}{c}\text { Darlington } \\
\text { Generation } \\
\text { Station, Ontario }\end{array}$ & - & $\begin{array}{l}\text { Ordovician } \\
\text { limestone }\end{array}$ & $228.0-300.0$ & $10.5-11.3$ & $17.2-19.6$ & $\mathrm{~N} 70 \mathrm{E} \pm 7^{\circ}$ & $\mathrm{HF}$ & [20] \\
\hline
\end{tabular}




\section{Continued}

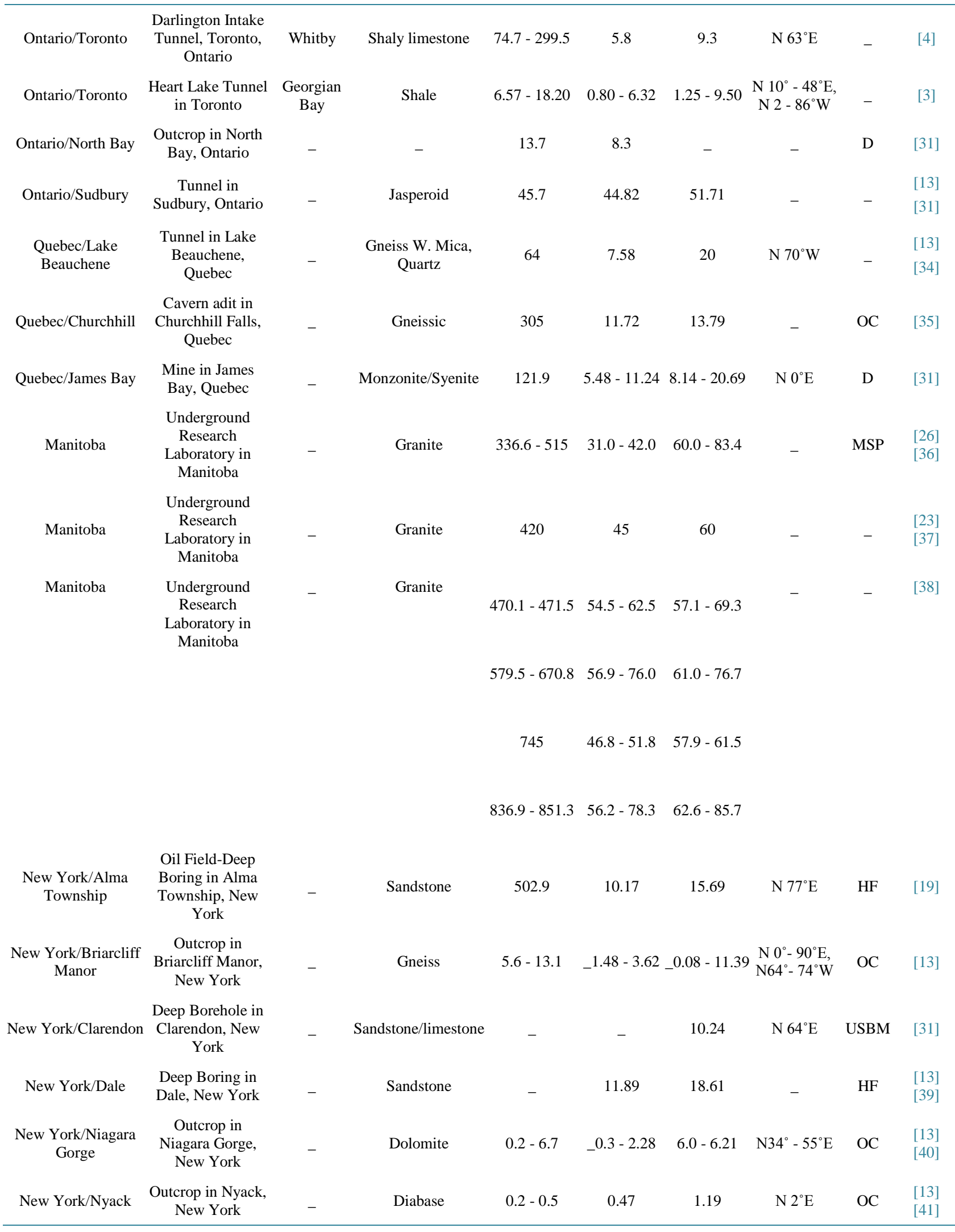




\section{Continued}

\begin{tabular}{|c|c|c|c|c|c|c|c|c|c|}
\hline New York/Rochester & $\begin{array}{c}\text { Sewer System in } \\
\text { Rochester, New } \\
\text { York }\end{array}$ & - & Dolomite & $7.5-15.4$ & _4.87 - 10.43 & $5.56-29.89$ & $\begin{array}{l}\mathrm{N} 10^{\circ}-86^{\circ} \mathrm{E} \\
\mathrm{N} 80^{\circ}-82^{\circ} \mathrm{W}\end{array}$ & OC & {$[42]$} \\
\hline New York/Somerset & $\begin{array}{c}\text { Outcrop in } \\
\text { Somerset, New } \\
\text { York }\end{array}$ & - & Sandstone & 8.5 & 3.17 & 4.41 & $\mathrm{~N} 15^{\circ} \mathrm{W}$ & OC & $\begin{array}{c}\text { [13] } \\
\text { [43] [44] }\end{array}$ \\
\hline New York/Sterling & $\begin{array}{c}\text { Outcrop in } \\
\text { Sterling, New York }\end{array}$ & - & Sandstone & $10.1-32.3$ & $4.59-6.55$ & $8.27-10.34$ & $\mathrm{~N} 22^{\circ}-90^{\circ} \mathrm{W}$ & OC & $\begin{array}{c}{[13]} \\
{[43][44]}\end{array}$ \\
\hline Illinois & $\begin{array}{c}\text { Oil Field-Deep } \\
\text { Boring in southern } \\
\text { Illinois }\end{array}$ & - & Carbonate & 99.1 & 2.41 & 7.76 & $\mathrm{~N} 62^{\circ} \mathrm{E}$ & OC & [17] \\
\hline \multirow[t]{3}{*}{ Michigan } & Deep Boring in & - & Shale & 5108 & 95 & 135 & - & OC & [15] \\
\hline & Michigan & & Sandstone & 3660 & 67 & 90 & & & \\
\hline & & & Dolomite & 3805 & 42 & 56 & & & \\
\hline Minnesota/Coldspring & $\begin{array}{l}\text { Quarry in } \\
\text { Coldspring, } \\
\text { Minnesota }\end{array}$ & - & Granite & 15 & 5.58 & 16.48 & $\mathrm{~N} 40^{\circ} \mathrm{E}$ & OC & [12] \\
\hline Minnesota/Ely & $\begin{array}{l}\text { Tunnel in Ely, } \\
\text { Minnesota }\end{array}$ & - & Gabbro & 305 & 10.3 & 16.5 & - & OC & [12] \\
\hline Minnesota/St. Cloud & $\begin{array}{l}\text { Quarry in St. } \\
\text { Cloud, Minnesota }\end{array}$ & - & Granite & - & 10.58 & 15.1 & $\mathrm{~N} 50^{\circ} \mathrm{E}$ & $\mathrm{D}$ & [45] \\
\hline Ohio & Boring in Ohio & - & Shale & $10.3-18.6$ & $4.69-32.41$ & $5.58-38.13$ & $\begin{array}{l}\mathrm{N} 45^{\circ}-83^{\circ} \mathrm{W} \\
\mathrm{N} 54^{\circ}-86^{\circ} \mathrm{E}\end{array}$ & OC & [13] \\
\hline Ohio/Barberton & $\begin{array}{c}\text { Mine in Barberton, } \\
\text { Ohio }\end{array}$ & - & Limestone & 701 & 23.44 & 44.82 & $\mathrm{~N} 90^{\circ} \mathrm{W}$ & $\mathrm{HF}$ & [21] \\
\hline Ohio/Falls Township & $\begin{array}{l}\text { Oil Field-Deep } \\
\text { Boring in Falls } \\
\text { Township, Ohio }\end{array}$ & - & Sandstone & 808 & 11.2 & 24.13 & $\mathrm{~N} 64^{\circ} \mathrm{E}$ & OC & [17] \\
\hline $\begin{array}{c}\text { Ohio/Hocking State } \\
\text { Forest }\end{array}$ & $\begin{array}{l}\text { Outcrop in } \\
\text { Hocking State } \\
\text { Forest, Ohio }\end{array}$ & - & Sandstone & $0.9-1.2$ & 0.37 & 0.63 & $\begin{array}{c}\mathrm{N} 61^{\circ} \mathrm{E}, \mathrm{N} \\
83^{\circ} \mathrm{E}\end{array}$ & OC & [14] \\
\hline Wisconsin/Montello & $\begin{array}{l}\text { Deep Boring in } \\
\text { Montello, } \\
\text { Wisconsin }\end{array}$ & - & Granite & $75.0-188.1$ & $6.2-8.2$ & $14.0-20.0$ & $\mathrm{~N} 63^{\circ} \mathrm{E} \pm 20^{\circ}$ & $\mathrm{HF}$ & [13] [46] \\
\hline
\end{tabular}

D: door stopper with South African CSIR strain cell; HF: hydro-fracturing technique; MSP: modified stress path method [16]; OC: over coring technique; USBM: the US bureau of mines deformation meter. 
Table 2. Intact rock strength and deformation properties.

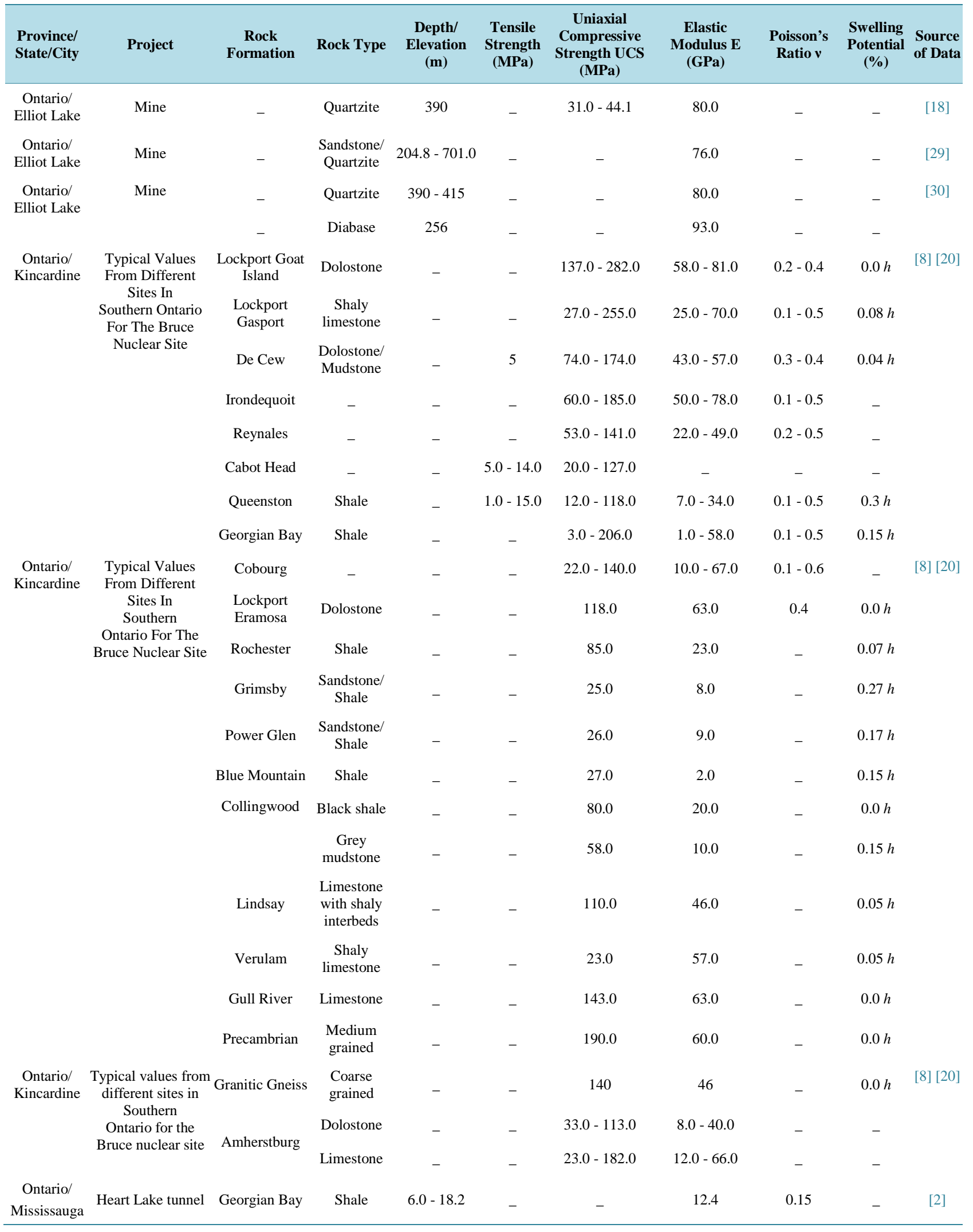




\section{Continued}

\begin{tabular}{|c|c|c|c|c|c|c|c|c|c|c|}
\hline $\begin{array}{c}\text { Ontario/ } \\
\text { Niagara Falls }\end{array}$ & $\begin{array}{c}\text { Sir Adam Beck } \\
\text { Niagara generating } \\
\text { station (SABNGS) } \\
\text { No. } 3\end{array}$ & Queenston & Shale & $\begin{array}{l}95.64- \\
114.33\end{array}$ & - & - & - & - & $\begin{array}{l}0.22-0.34 h \\
0.37-0.54 v\end{array}$ & $\begin{array}{l}{[6]} \\
{[8]}\end{array}$ \\
\hline \multirow[t]{3}{*}{$\begin{array}{l}\text { Southern } \\
\text { Ontario }\end{array}$} & $\begin{array}{l}\text { Different Sites In } \\
\text { Southern Ontario }\end{array}$ & Rochester & $\begin{array}{l}\text { Interbedded } \\
\text { shale and } \\
\text { Dolomite }\end{array}$ & - & - & $20.0-40.0$ & 20.0 & - & - & [1] \\
\hline & & Georgian Bay & $\begin{array}{l}\text { Interbedded } \\
\text { shale/Siltstone/ } \\
\text { Mudstone/ } \\
\text { Limestone }\end{array}$ & - & - & $30.0-190.0$ & $20.0-40.0$ & - & - & \\
\hline & & Collingwood & $\begin{array}{c}\text { Interbedded } \\
\text { shale/Mudsto } \\
\text { ne }\end{array}$ & - & - & $20.0-70.0$ & $\begin{array}{c}7.0-20.0 v \\
14.0-35.0 h\end{array}$ & - & - & \\
\hline $\begin{array}{l}\text { Ontario/ } \\
\text { Sudbury }\end{array}$ & Tunnel & - & Jasperoid & 45.7 & - & - & 83.0 & - & - & $\begin{array}{l}{[13]} \\
{[33]}\end{array}$ \\
\hline \multirow{3}{*}{$\begin{array}{l}\text { Ontario/ } \\
\text { Thorold }\end{array}$} & & & $\begin{array}{l}\text { Dolomitic } \\
\text { limestone }\end{array}$ & $16.2-17.3$ & - & - & $73.0-74.0$ & - & - & \\
\hline & & & $\begin{array}{l}\text { Shaly } \\
\text { limestone }\end{array}$ & $18.3-18.6$ & - & - & 43.0 & - & - & \\
\hline & & & limestone & $19.8-24.7$ & - & - & 55.0 & - & - & \\
\hline \multirow[t]{4}{*}{$\begin{array}{l}\text { Ontario/ } \\
\text { Thorold }\end{array}$} & Thorold tunnel & $\begin{array}{l}\text { Gasport } \\
\text { member of }\end{array}$ & Dolomite & $12.7-53.1$ & - & - & $71.0-73.0$ & $0.27-0.3$ & - & [24] \\
\hline & & $\begin{array}{l}\text { Lockport/De } \\
\text { Cew }\end{array}$ & $\begin{array}{l}\text { Dolomitic } \\
\text { limestone }\end{array}$ & 56.6 & - & - & 74.0 & 0.3 & - & \\
\hline & & formations & $\begin{array}{c}\text { Shaly } \\
\text { limestone }\end{array}$ & $60.0-61.0$ & - & - & 43.0 & 0.25 & - & \\
\hline & & & $\begin{array}{l}\text { Fossiliferous } \\
\text { limestone }\end{array}$ & 65.0 & - & - & 55.0 & 0.3 & - & \\
\hline \multirow[t]{2}{*}{$\begin{array}{l}\text { Ontario/ } \\
\text { Toronto }\end{array}$} & $\begin{array}{l}\text { Darlington intake } \\
\text { tunnel }\end{array}$ & Whitby & $\begin{array}{c}\text { Shaly } \\
\text { limestone }\end{array}$ & 83.4 & - & $52.0-63.3 h$ & $52.9-54.6 h$ & $0.25-0.27 h$ & - & $\begin{array}{l}{[25]} \\
{[47]}\end{array}$ \\
\hline & & & & $84.4-84.7$ & - & $87.6-88.2 v$ & $39.6-43.6 v$ & $0.34-0.37 v$ & - & \\
\hline $\begin{array}{l}\text { Ontario/ } \\
\text { Toronto }\end{array}$ & Domed stadium & Georgian Bay & Shale & $19.8-26.3$ & - & $11.2-17.2$ & 2.2 & 0.3 & - & {$[4]$} \\
\hline \multirow[t]{4}{*}{$\begin{array}{l}\text { Ontario/ } \\
\text { Wawa }\end{array}$} & Mine & - & Siderite & 365.8 & - & - & $67.6-118.0$ & - & - & [28] \\
\hline & & & Tuff & 478.5 & - & - & $68.3-115.8$ & - & - & \\
\hline & & & Meta - diorite & 573.0 & - & - & $52.4-70.3$ & - & - & \\
\hline & & & Chert & 573.0 & - & - & $51.7-80.0$ & - & - & \\
\hline \multirow[t]{7}{*}{$\begin{array}{l}\text { Southern } \\
\text { Ontario }\end{array}$} & $\begin{array}{l}\text { Research program } \\
\text { for the National }\end{array}$ & Lockport & $\begin{array}{l}\text { Dolomitic } \\
\text { limestone }\end{array}$ & $157.0-168.0$ & - & $180.0 h$ & $76.0 h$ & $0.14-0.33$ & $0.02 h$ & [7] \\
\hline & $\begin{array}{c}\text { Research Council of } \\
\text { Canada, } \\
\text { different sites in } \\
\text { Southern Ontario }\end{array}$ & & $\begin{array}{l}\text { Gasport shaly } \\
\text { limestone }\end{array}$ & - & $\begin{array}{l}- \\
-\end{array}$ & $\begin{array}{l}200.0 \mathrm{v} \\
105.0 \mathrm{~h}\end{array}$ & $\begin{array}{l}67.0 \mathrm{v} \\
44.0 \mathrm{~h}\end{array}$ & $\begin{array}{l}- \\
-\end{array}$ & $\begin{array}{l}0.01 v \\
0.08 h\end{array}$ & \\
\hline & & & & & - & $120.0 v$ & $27.0 v$ & - & $0.08 v$ & \\
\hline & & Rochester & Shale & $26.2-26.52$ & - & $70.0 \mathrm{~h}$ & $27.0 h$ & - & $0.07 h 0.16 v$ & \\
\hline & & Georgian Bay & Shale & $10.17-15.33$ & - & $35.0 h$ & $21.0 h$ & $0.06-0.25$ & $\begin{array}{c}0.03-0.14 h \\
0.2-0.22 v\end{array}$ & \\
\hline & & Collingwood & $\begin{array}{c}\text { Grey } \\
\text { Mudstone }\end{array}$ & $17.0-24.64$ & - & $35.0 h 60.0 v$ & $23.0 h 10.0 v$ & 0.2 & $\begin{array}{l}0.15 h \\
0.45 v\end{array}$ & \\
\hline & & & Black shale & $17.0-24.64$ & - & $\begin{array}{l}70.0 \mathrm{~h} \\
80.0 \mathrm{v}\end{array}$ & $\begin{array}{l}37.0 \mathrm{~h} \\
20.0 \mathrm{v}\end{array}$ & $0.1-0.25$ & $\begin{array}{l}0.0 \mathrm{~h} \\
0.0 \mathrm{v}\end{array}$ & \\
\hline
\end{tabular}




\section{Continued}

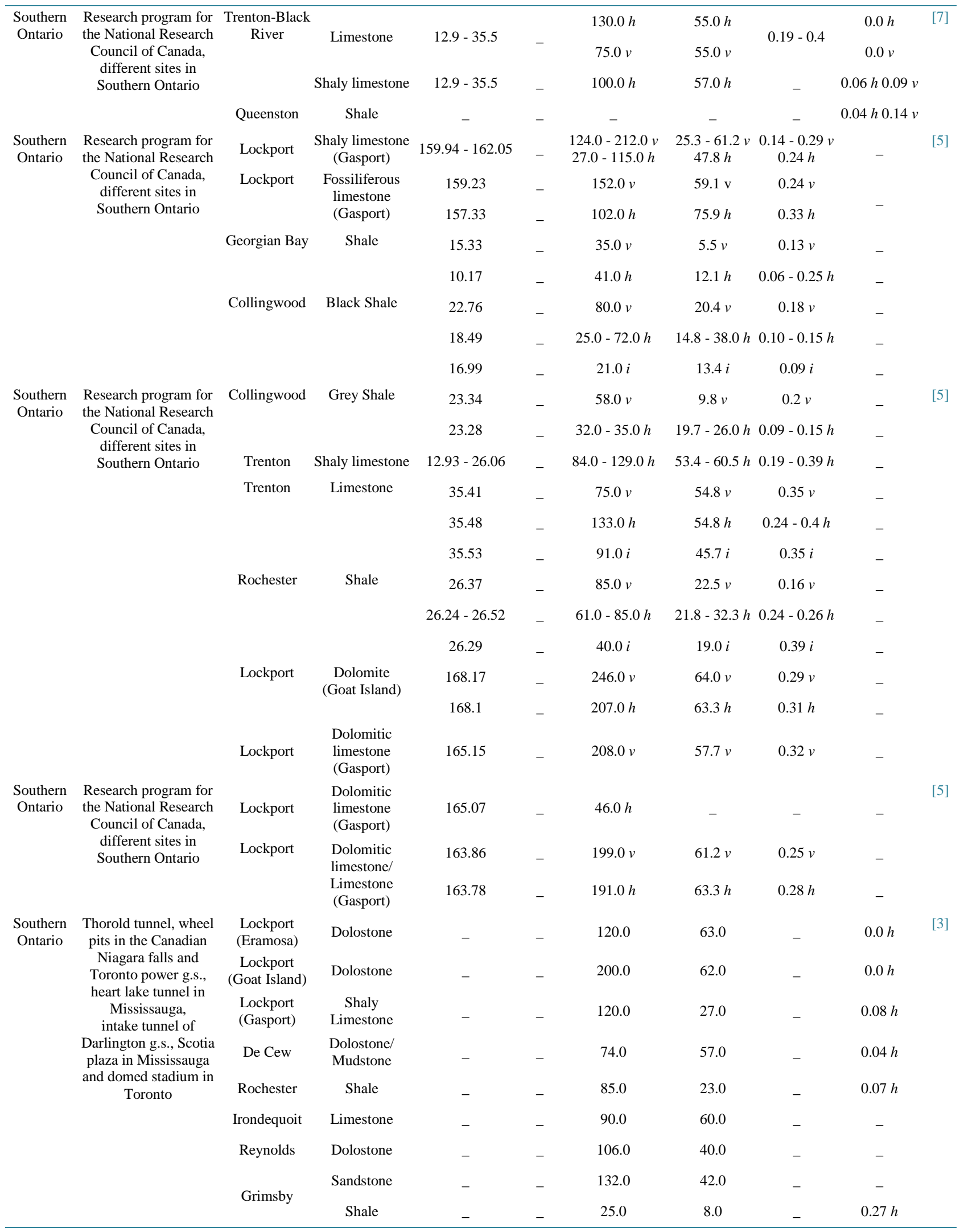




\section{Continued}

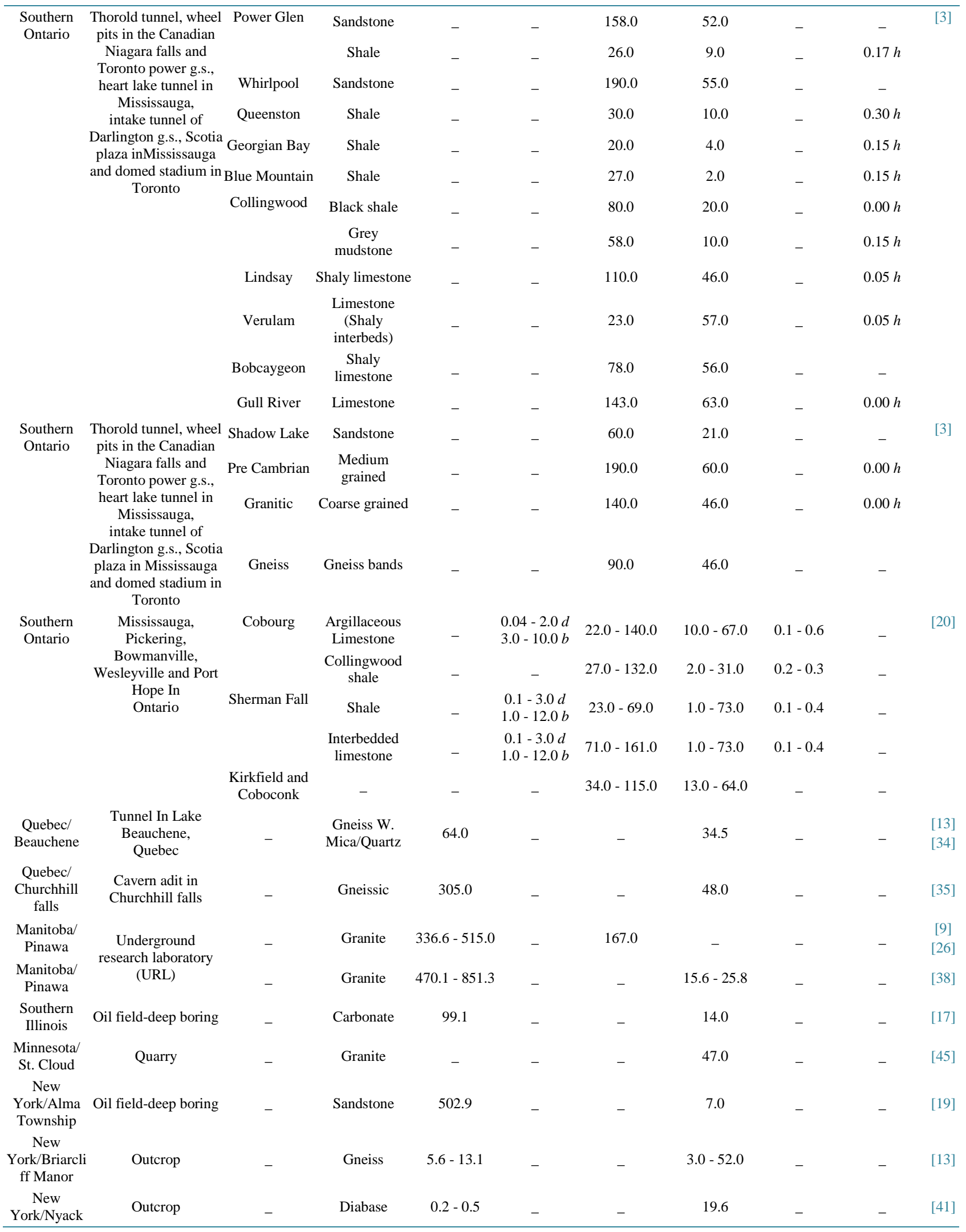


H. M. S. Al-Maamori et al.

\section{Continued}

\begin{tabular}{|c|c|c|c|c|c|c|c|c|c|c|}
\hline $\begin{array}{c}\text { New } \\
\text { York/Niagara } \\
\text { gorge }\end{array}$ & Outcrop & - & Dolomite & $0.2-6.7$ & - & - & 24.0 & - & - & $\begin{array}{l}{[13]} \\
{[40]}\end{array}$ \\
\hline $\begin{array}{c}\text { New } \\
\text { York/Rochest } \\
\text { er }\end{array}$ & Sewer system & - & Dolomite & - & - & - & 50.7 - 91.7 & - & - & {$[42]$} \\
\hline $\begin{array}{c}\text { New } \\
\text { York/Somers } \\
\text { et }\end{array}$ & Outcrop & - & Sandstone & 8.5 & - & - & 17.0 & - & - & $\begin{array}{l}{[13]} \\
{[43]} \\
{[44]}\end{array}$ \\
\hline $\begin{array}{l}\text { New York/ } \\
\text { Sterling }\end{array}$ & Outcrop & - & Sandstone & $10.1-32.3$ & - & - & 33.0 & - & - & $\begin{array}{l}{[13]} \\
{[43]} \\
{[44]}\end{array}$ \\
\hline Ohio & Boring & - & Shale & $10.3-18.6$ & - & - & $13.0-28.0$ & - & - & [13] \\
\hline $\begin{array}{l}\text { Ohio/Barbert } \\
\text { on }\end{array}$ & Mine & - & Limestone & 701.0 & - & - & $55.0-67.0$ & - & - & [21] \\
\hline $\begin{array}{l}\text { Ohio/Bellefo } \\
\text { untaine }\end{array}$ & Quarry & Gasport & $\begin{array}{l}\text { Limestone/ } \\
\text { Dolomite }\end{array}$ & $0.2-1.0$ & - & - & 34.8 & - & - & [13] \\
\hline $\begin{array}{l}\text { Ohio/Falls } \\
\text { Township }\end{array}$ & $\begin{array}{l}\text { Oil Field - Deep } \\
\text { boring }\end{array}$ & - & Sandstone & 808.0 & - & - & 10.0 & - & - & [17] \\
\hline $\begin{array}{c}\text { Ohio/Hockin } \\
\text { g State } \\
\text { Forest }\end{array}$ & Outcrop & - & Sandstone & $0.9-1.2$ & - & - & 7.8 & - & - & {$[14]$} \\
\hline Ohio/Kenton & Quarry & - & $\begin{array}{c}\text { Limestone/ } \\
\text { Dolomite }\end{array}$ & $0.2-1.0$ & - & - & 34.8 & - & - & [13] \\
\hline Ohio/Lima & Quarry & - & $\begin{array}{l}\text { Limestone/ } \\
\text { Dolomite }\end{array}$ & $0.2-1.0$ & - & - & 34.8 & - & - & [13] \\
\hline $\begin{array}{l}\text { Ohio/ } \\
\text { Sydney }\end{array}$ & Quarry & - & $\begin{array}{l}\text { Limestone/ } \\
\text { Dolomite }\end{array}$ & $0.2-1.0$ & - & - & 34.8 & - & - & [13] \\
\hline $\begin{array}{l}\text { Wisconsin/ } \\
\text { Montello }\end{array}$ & Deep Boring & - & Granite & $75.0-188.1$ & - & - & $52.0-56.0$ & - & - & [46] \\
\hline
\end{tabular}

$d$ : result from direct tension test; $b$ : results from Brazilian test; $v$ : results from vertically cored samples/or measurements in the vertical direction; $h$ : results from horizontally cored samples/or measurements in the horizontal direction ; $i$ : results from inclined $45^{\circ}$ cored samples with respect to the bedding planes. 
Table 3. Dynamic properties of intact rocks.

\begin{tabular}{|c|c|c|c|c|c|c|c|c|c|c|}
\hline $\begin{array}{l}\text { Province/ } \\
\text { State/City }\end{array}$ & Project & $\begin{array}{c}\text { Rock } \\
\text { Formation }\end{array}$ & Rock Type & $\begin{array}{l}\text { Depth/ } \\
\text { Elevation } \\
\text { (m) }\end{array}$ & $\begin{array}{c}\text { Mass } \\
\text { Density } \\
\left(\mathbf{M g} / \mathbf{m}^{3}\right)\end{array}$ & $\begin{array}{c}\text { Compressive } \\
\text { Wave } \\
\text { Velocity } \\
(\mathrm{Km} / \mathrm{s})\end{array}$ & $\begin{array}{c}\text { Shear } \\
\text { Wave } \\
\text { Velocity } \\
(\mathrm{Km} / \mathbf{s})\end{array}$ & $\begin{array}{l}\text { Dynamic } \\
\text { Poisson's } \\
\text { Ratio vdy. }\end{array}$ & $\begin{array}{c}\text { Dynamic } \\
\text { Modulus } \\
\text { Edy. (GPa) }\end{array}$ & $\begin{array}{l}\text { Source } \\
\text { of Data }\end{array}$ \\
\hline \multirow{12}{*}{$\begin{array}{l}\text { Southern } \\
\text { Ontario }\end{array}$} & \multirow{12}{*}{$\begin{array}{l}\text { Research Program } \\
\text { For The National } \\
\text { Research Council } \\
\text { of Canada, } \\
\text { Different Sites in } \\
\text { Southern Ontario }\end{array}$} & \multirow[t]{2}{*}{$\begin{array}{l}\text { Lockport } \\
\text { (Gasport) }\end{array}$} & \multirow[t]{2}{*}{$\begin{array}{c}\text { Shaly } \\
\text { limestone }\end{array}$} & 159.94 & $2.68-2.69 v$ & - & - & - & $44.3-67.5 v$ & \multirow[t]{12}{*}{ [5] } \\
\hline & & & & 162.05 & $2.68-2.76 h$ & _- & _ & - & $63.3-71.0 h$ & \\
\hline & & \multirow{2}{*}{$\begin{array}{l}\text { Lockport } \\
\text { (Gasport) }\end{array}$} & \multirow[t]{2}{*}{$\begin{array}{l}\text { Fossiliferous } \\
\text { limestone }\end{array}$} & 159.23 & $2.71 v$ & - & - & - & $66.8 v$ & \\
\hline & & & & 157.33 & $2.72 h$ & - & - & - & $73.1 h$ & \\
\hline & & \multirow[t]{3}{*}{ Georgian Bay } & \multirow[t]{3}{*}{ Shale } & 15.33 & $2.55 v$ & - & - & - & $19.2 v$ & \\
\hline & & & & 10.17 & $2.60 h$ & - & - & - & $38.2 h$ & \\
\hline & & & & 12.1 & $2.54 i$ & - & - & - & $19.0 i$ & \\
\hline & & \multirow[t]{3}{*}{ Collingwood } & \multirow[t]{3}{*}{ Black shale } & 22.76 & $2.53 v$ & - & - & - & $27.4 v$ & \\
\hline & & & & 18.49 & $2.53-2.56 h$ & - & - & - & $51.3-58.4 h$ & \\
\hline & & & & 16.99 & $2.58 i$ & - & - & - & $37.3 i$ & \\
\hline & & \multirow[t]{2}{*}{ Collingwood } & \multirow[t]{2}{*}{ Grey shale } & 23.34 & $2.6 v$ & - & - & - & $4.9 v$ & \\
\hline & & & & 23.27 & $2.61-2.64 h$ & - & - & - & $42.2-49.2 h$ & \\
\hline \multirow{12}{*}{$\begin{array}{l}\text { Southern } \\
\text { Ontario }\end{array}$} & \multirow{12}{*}{$\begin{array}{l}\text { Research Program } \\
\text { For The National } \\
\text { Research Council } \\
\text { of Canada, } \\
\text { Different Sites in } \\
\text { Southern Ontario }\end{array}$} & Collingwood & Grey shale & 23.29 & $2.6 i$ & - & - & - & - & \multirow[t]{12}{*}{ [5] } \\
\hline & & Collingwood & $\begin{array}{c}\text { Shaly } \\
\text { limestone }\end{array}$ & $12.93-26.06$ & 2.68 & - & - & - & - & \\
\hline & & Trenton & Limestone & 35.41 & $2.68 v$ & - & - & - & - & \\
\hline & & & & 35.53 & $2.68 h$ & - & - & - & - & \\
\hline & & \multirow{4}{*}{ Rochester } & \multirow{4}{*}{ Shale } & 35.48 & $2.85 i$ & - & - & - & - & \\
\hline & & & & 26.37 & $2.77 v$ & - & - & - & $38.7 v$ & \\
\hline & & & & $26.24-26.5$ & $2.68-2.72 h$ & - & - & - & $39.4 h$ & \\
\hline & & & & 26.29 & $2.74 i$ & - & - & - & $21.8 i$ & \\
\hline & & \multirow{3}{*}{$\begin{array}{l}\text { Lockport } \\
\text { (Goat } \\
\text { Island) }\end{array}$} & \multirow[t]{3}{*}{ Dolomite } & 169.37 & 2.76 & - & - & - & $61.9 v$ & \\
\hline & & & & 168.8 & 2.76 & - & - & - & $70.3-80.2 h$ & \\
\hline & & & & 169.21 & 2.77 & - & - & - & $74.5 i$ & \\
\hline & & $\begin{array}{l}\text { Lockport } \\
\text { (Gasport) }\end{array}$ & $\begin{array}{l}\text { Dolomitic } \\
\text { limestone }\end{array}$ & 165.66 & $2.72 v$ & - & - & - & $73.8 v$ & \\
\hline \multirow{5}{*}{$\begin{array}{l}\text { Southern } \\
\text { Ontario }\end{array}$} & \multirow{5}{*}{$\begin{array}{l}\text { Research Program } \\
\text { For The National } \\
\text { Research Council } \\
\text { of Canada, } \\
\text { Different Sites in } \\
\text { Southern Ontario }\end{array}$} & \multirow[t]{2}{*}{$\begin{array}{l}\text { Lockport } \\
\text { (Gasport) }\end{array}$} & \multirow[t]{2}{*}{$\begin{array}{l}\text { Dolomitic } \\
\text { limestone }\end{array}$} & 165.57 & $2.76 h$ & - & - & - & $70.3-86.5 h$ & \multirow[t]{5}{*}{ [5] } \\
\hline & & & & 165.74 & $2.72 i$ & - & - & - & $69.6 i$ & \\
\hline & & \multirow[t]{3}{*}{$\begin{array}{l}\text { Lockport } \\
\text { (Gasport) }\end{array}$} & \multirow{3}{*}{$\begin{array}{l}\text { Dolomitic } \\
\text { limestone/ } \\
\text { Limestone }\end{array}$} & 164.06 & $2.72 v$ & - & - & - & $47.8 v$ & \\
\hline & & & & 164.17 & $2.71-2.72 h$ & - & - & - & $53.4-66.1 h$ & \\
\hline & & & & $164 . .01$ & $2.76 i$ & - & - & - & $60.5 i$ & \\
\hline Ontario/ & Darlington intake & Whitby & Shaly & 83.4 & $2.58-2.70$ & $5.1-5.12 v$ & $1.01-2.49$ & $0.34-0.37 v$ & $39.6-43.6 v$ & [4] \\
\hline & & & & $84.4-84.7$ & - & $4.92-5.13 h$ & - & $0.25-0.27 h$ & $52.9-54.6 h$ & [25] \\
\hline $\begin{array}{l}\text { Ontario } \\
\text { /Niagara } \\
\text { Falls }\end{array}$ & $\begin{array}{l}\text { Sir Adam Beck } \\
\text { Niagara } \\
\text { generating station } \\
\text { (SABNGS) No. } 3\end{array}$ & Queenston & Shale & $95.64-114.33$ & $2.66-2.68$ & $3.48-4.28$ & - & - & - & {$[6]$} \\
\hline
\end{tabular}

$v$ : results from vertically cored samples/or measurements in the vertical direction; $h$ : results from horizontally cored samples/or measurements in the horizontal direction; $i$ : results from inclined $45^{\circ}$ cored samples with respect to the bedding planes. 
Scientific Research Publishing (SCIRP) is one of the largest Open Access journal publishers. It is currently publishing more than 200 open access, online, peer-reviewed journals covering a wide range of academic disciplines. SCIRP serves the worldwide academic communities and contributes to the progress and application of science with its publication.

Other selected journals from SCIRP are listed as below. Submit your manuscript to us via either submit@scirp.org or Online Submission Portal.
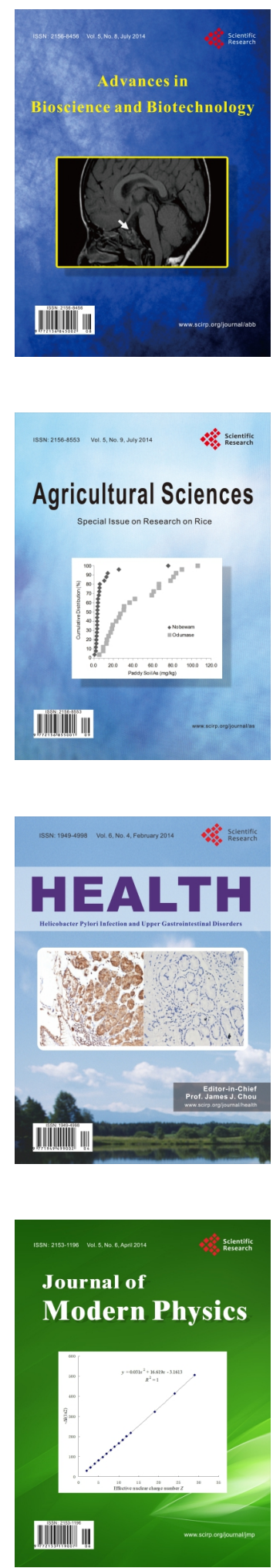
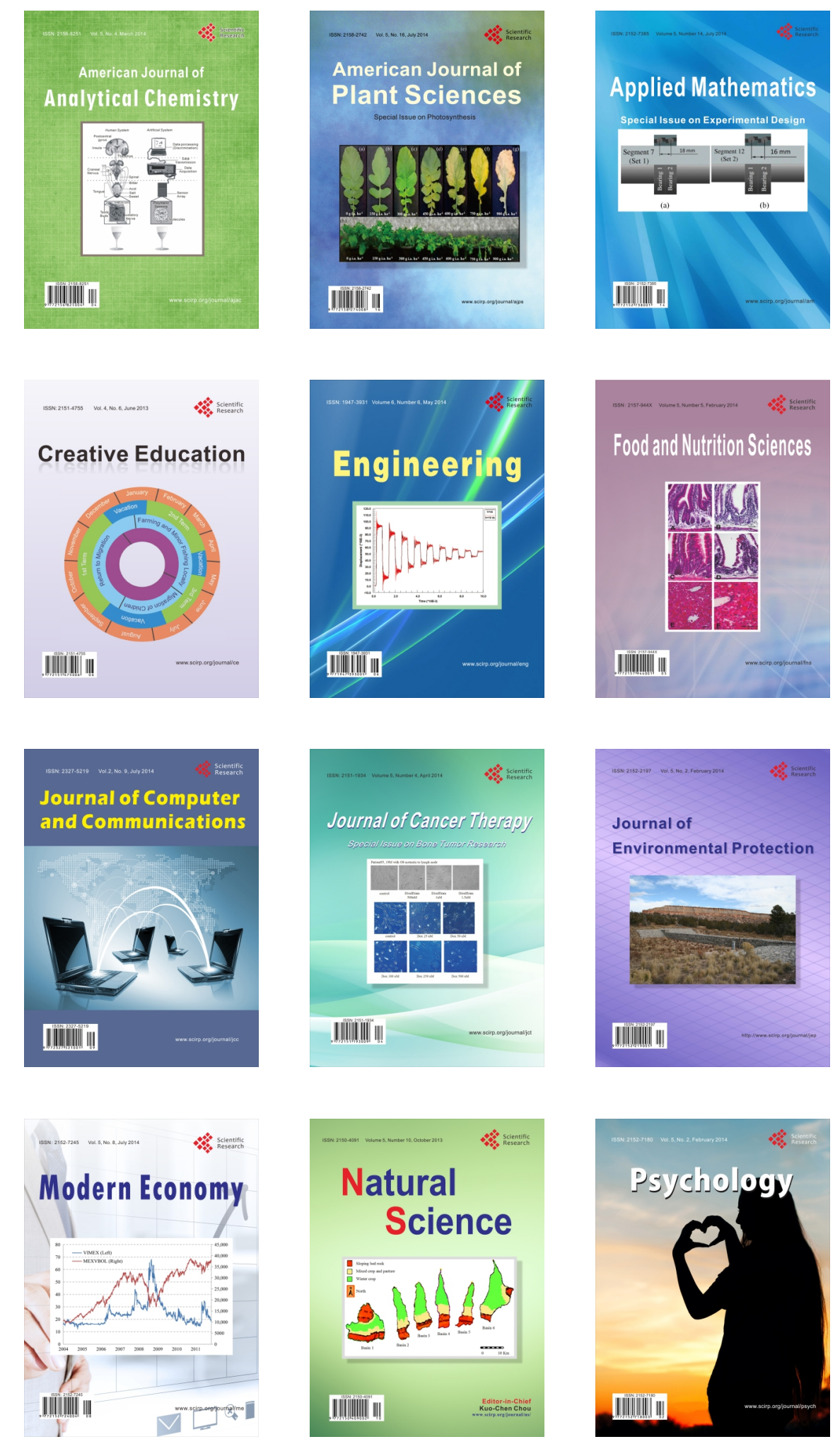